\title{
Question of Mobility Pilot Study: Students' Competency, Capacity and Reality
}

\author{
Semira Galijasevic (Corresponding author) \\ Department of Chemistry, Faculty of Science, University of Sarajevo \\ Zmaja od Bosne 33-35, 71000, Sarajevo, Bosnia and Herzegovina
}

Tel: 387-33-279-917Ｅ-mail: semiragalijasevic@ gmail.com

\begin{abstract}
Zalkida Hadzibegovic
Department of Physics, Faculty of Science, University of Sarajevo

Zmaja od Bosne 33-35, 71000, Sarajevo, Bosnia and Herzegovina
\end{abstract}

Tel: 387-33-279-996Ｅ-mail: E-mail: zalkida.hadzibegovic@gmail.com

Received: January 9, 2012 Accepted: February 27, 2012 Published: March 11, 2012

doi:10.5296/ije.v4i1.1274 URL: http://dx.doi.org/10.5296/ije.v4i1.1274

\begin{abstract}
Globalization as a worldwide process has significant implications in the area of education. In relation to this trend, the main challenge is to prepare students for the role of competent global citizens. Thus, we tested selected group of students of chemistry in attempt to measure their understanding of global trends in education. Results show positive attitudes towards student mobility, but no vision to develop competence and capacity that will make them quality applicants for international mobility programs. Scarce examples of students engagement in global educational trends only magnifies the need for well researched and organized approach in this area.
\end{abstract}

Keywords: International education, Mobility, Competency, Science 


\section{Introduction}

Living in a global society requires trained individuals who will have capacity to understand different individuals and societies as a whole (Brodin, 2010) based on collected information. For European countries that are on their road to European integration, it is of crucial importance to have educated individuals with international experience capable of leading the process not only for economical and political purposes but also for cultural, educational and scientific purposes.

Brux and Blake in 2010 legitimately raised question why there are no more participants in exchange programs, at this time of the current globalization process, which characterize this modern civilization. According to Tarrant (2009) the most important factor in a new worldview (global citizenship) are studies outside someone own country, giving priority to different standards of behavior towards the environment in which global citizen works through a system of "sustainable transformative learning." Offering a possible answer to difficulties that multicultural students might have (Brux, \& Fry, 2010), categories identified by Washington (1998) are still valid today (Salisbury et al., 2009). Some of those categories that may characterize students from Bosnia and Herzegovina are the attitudes of individuals towards mobility as a way of participation in programs of multicultural exchanges, expectations, financial framework, the historical background and relevance of the curriculum for their own professional development or the perspective of the institution they come from (Brux \& Fry, 2010).

If these categories are briefly analyzed, we find arguments that are more affirming than limiting. BiH students participate, but not in large or significant numbers in mobility programs (mostly one-way student exchange program organized by the European Commission and US State Department). What are the attitudes towards this global trend in education of those students who do not participate or do not apply is not known, but positive opinion towards mobility in education and science has been observed generally at the institutions of higher education in $\mathrm{BiH}$. When it comes to professional expectations of our students, before the current global economic crisis, $60 \%$ of $\mathrm{BiH}$ students had seen their future outside of $\mathrm{BiH}$, while today, that number is somewhat different. It is not known whether current worldwide economical conditions or some other reasons are causing this shift.

$\mathrm{BiH}$ students rarely participate in scientific research projects during their education except during a degree program for master's and doctoral theses, due to the lack of funds for research projects. That is the main reason why they need to be involved in research, in a manner that promotes Erichsen \& Goldstein (2011), pointing to the necessity of participation of students in interdisciplinary research, the necessity "for elevating practice in the field of education and for solving broader problems in society ". According to Erichsen \& Goldstein (2011), particularly important is encouraging potential fund donors, to promote interdisciplinary research. Having the possibility to experience challenges in a new environment in the field of science and research, would help them to quickly engage "into new spaces of innovation".

Our research was prompted by a significant number of different exchange programs and 
numerous opportunities for students and staff in $\mathrm{BiH}$ to get involved in globalization and internationalization of education. Being aware of all difficulties and inadequate conditions for teaching and learning in $\mathrm{BiH}$ higher education system, we initiated a pilot study to find out the reasons for small number of $\mathrm{BiH}$ students participating in programs of student mobility in European countries or the USA. The most important results are presented in this paper.

\section{Research}

\subsection{Research questions}

The objective of our research was to examine barriers caused by language skills and educational reasons that hinder $\mathrm{BiH}$ students to participate in different mobility programs that are suggested as one of the important educational tools by Bologna Program (Bergen Communiqué, 2005; Benelux Communiqué, 2009). In order to indicate some of the possible reasons causing this problem, we designed a set of questions to diagnose and measure problems directly related to students awareness of current trends in globalization of education. We focused on these two research questions:

RQ1: Are BiH chemistry students competent and knowledgeable for participation in mobility programs?

RQ2: Is the method of integrated science and second languages knowledge an adequate content for increasing the abilities and willingness of $\mathrm{BiH}$ chemistry students to be involved in a mobility program?

\subsection{Participants and questionnaire content}

All questions included in the questionnaire are in some relationships with identified issues that we have been observing continuously for the last five years of teaching freshmen General Chemistry and General Physics courses in Chemistry Department.

According to observed issues among our students, we selected problem points as following:

(1) Learning tools issues

(2) Second language issues

(3) Issues connected with students' attitudes and openness to other education systems and mobility programs.

Questionnaire contained eleven questions separated in the four question groups:

QA - group of questions consists of two questions containing seven sub questions related to a different learning tools with answers offered on 5-point Likert scale (1 never, 5 all the time) as an option for both General Chemistry and General Physics classes, and one open question about textbooks recommended and used in a classes.

QB - group of questions that were covered by three multiple-choice questions about second language students' competencies.

QC - group of questions included two multiple-choice questions about students' learning time spent for exam preparation per week for corresponding courses.

QD - group of questions included three multiple-choice questions about students' attitudes and opinions about study in a foreign country and their plans to participate in a different 
mobility programs.

Data in our diagnostic pilot research study were collected in the first-semester freshmen General Physics class in the Department of Chemistry/Faculty of Science at University of Sarajevo, in fall semester of 2011 with 69 students participating in study (11 male and 58 female). The sample represents approximately $90 \%$ of the students enrolled in first year of study at Chemistry Department.

\section{Results}

\subsection{QA results and discussion}

In all educational levels, use of textbooks as a part of learning process is essential step in acquisition of required knowledge (Heyneman et al., 1978). In General Chemistry and Physics class syllabi at UNSA, Chemistry Department required and suggested textbooks are in the native language (Bosnian) and in English language. In General Chemistry classes following foreign language textbooks were recommended: Raymond Chang, Chemistry, McGraw-Hill: New York (any available edition) and Martin S. Silberberg, Chemistry: The Molecular Nature of Matter and Change, McGraw-Hill: New York (any available edition). These textbooks are widely used as required reading for General Chemistry classes mainly on US institutions of Higher Education and some International Colleges following US curriculum programs. (Davila et al., 2010). Our decision to recommend these textbooks was based on the good concept approach, sufficient number of problems, visual representations of chemistry processes and our previous experience with chemistry students using the same textbooks.Our results showed that students mainly use textbooks in chemistry and physics written in native language (around 84\%), while most of the students did not use suggested textbooks in English language according to their answers. Recommended native language textbooks in General Physics syllabus are used by $60 \%$ students and the recommended native language textbooks in General Chemistry syllabus are used by $71 \%$ students. (Data not shown). Besides, most students use lecture notes and PowerPoint presentations prepared by the teacher or downloaded from the Internet using the available content portals of some universities in the Balkans or in the world. Significant numbers of students, approximately $33 \%$ to $40 \%$ use study materials borrowed from their older colleagues for both courses, which indicates a passive approach towards preparation and development of study skills. Based on these data we can say that the general picture showing the type of learning resources used by first year students of chemistry in General Chemistry and General Physics class is not encouraging especially since the use of unreliable sources is dominating trend. These resources are mainly lecture notes or materials taken from older colleagues, as well as materials from the Internet, which according to our experience is mainly "Wikipedia" content. Total overview of the different sources of learning and preparation for General Physic and General Chemistry exams that are used by students are shown in Table 1 and Table 2 respectively.

At open type questions in which students were asked to list references (title and author) of textbooks used for studies, students gave responses that were generally expected, compliant with syllabus but only for textbooks in native language. Results, accordingly to defined 
groups, are presented in Figure 1. However, significant number of students did not give an answer implying that textbook is not their major learning tool. Consequently, use of English textbooks, as additional learning sources, is not likely for this group of students.

Table 1: Identification of students' learning materials used for General Physics exam preparation in percentages

\begin{tabular}{l|l|l|r|l|l}
\hline \multicolumn{1}{c|}{ Answers } & \multicolumn{1}{c|}{1} & \multicolumn{1}{c|}{2} & \multicolumn{1}{c|}{3} & \multicolumn{1}{c}{4} & \multicolumn{1}{c}{5} \\
\hline Internet sources & 29.9 & 17.9 & 28.4 & 14.9 & 9.0 \\
PP presentations from lectures & 37.9 & 15.2 & 19.7 & 18.2 & 9.1 \\
Personal lecture notes & 2.9 & 1.5 & 13.2 & 2.53 & 58.8 \\
Written materials from senior students & 16.9 & 16.2 & 23.5 & 30.9 & 13.2 \\
\hline
\end{tabular}

Description for the above table: 1-Never; 2-Rearly; 3-Ocassionaly; 4- Frequently; 5-All the time

Table 2: Identification of students' learning materials used for General Chemistry exam preparation in percentages

\begin{tabular}{l|l|l|r|l|l}
\hline \multicolumn{1}{c|}{ Answers } & \multicolumn{1}{c|}{1} & \multicolumn{1}{c|}{2} & \multicolumn{1}{c|}{3} & \multicolumn{1}{c}{4} & \multicolumn{1}{c}{5} \\
\hline Internet sources & 19.7 & 15.2 & 36.4 & 22.7 & 6.1 \\
PP presentations from lectures & 23.9 & 9.0 & 32.8 & 25.4 & 9.0 \\
Personal lecture notes & 1.5 & 4.6 & 13.8 & 21.5 & 58.5 \\
Written materials from senior students & 18.5 & 21.5 & 24.6 & 18.5 & 16.9 \\
\hline
\end{tabular}

Description for the above table: 1-Never; 2-Rearly; 3-Ocassionaly; 4- Frequently; 5-All the time

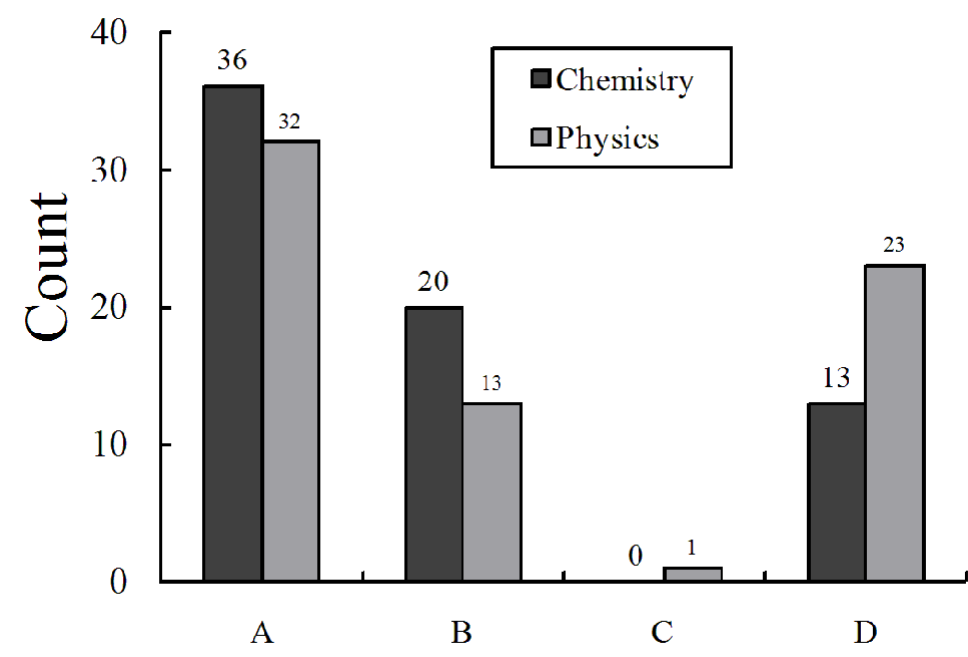

Figure 1: Distribution of students answers $(\mathrm{N}=69)$ to the question testing their knowledge of required literature in General Chemistry and General Physics class

Description for the above figure: A-Textbook title and author name known; B-Title only know; C-Author name only; D-Not answered 


\section{Macrothink}

\subsection{QB results and discussion}

Since the English is dominant language of scientific communication nowadays, we tested student's competencies in this area. Self-evaluated knowledge of English language by students participating in this study is presented in Table 3.

Table 3: Self evaluated knowledge of English language by students participating in this study

\begin{tabular}{l|l}
\hline \multicolumn{1}{c|}{ Answer } & \multicolumn{1}{c}{$\%$} \\
\hline I do not know English & 1.5 \\
weak knowledge & 22.0 \\
good & 27.5 \\
very good & 40.0 \\
excellent & 6.0 \\
not answered & 3.0 \\
\hline
\end{tabular}

Only $6 \%$ of students believe that they have excellent English language indicating the possible reasons why students do not apply and rarely participate in the international programs of exchange, or continue their education at universities where language of communication is English. We find that $67.5 \%$ of students assess their knowledge as good. These groups of students combined together makes a significant percentage of students (more than $70 \%$ ) that have the necessary knowledge and skills to independently and without any difficulties undertake studies using English language study literature. These results should directly translate to students' use of General Chemistry and General Physics textbooks in English (Figure 2).

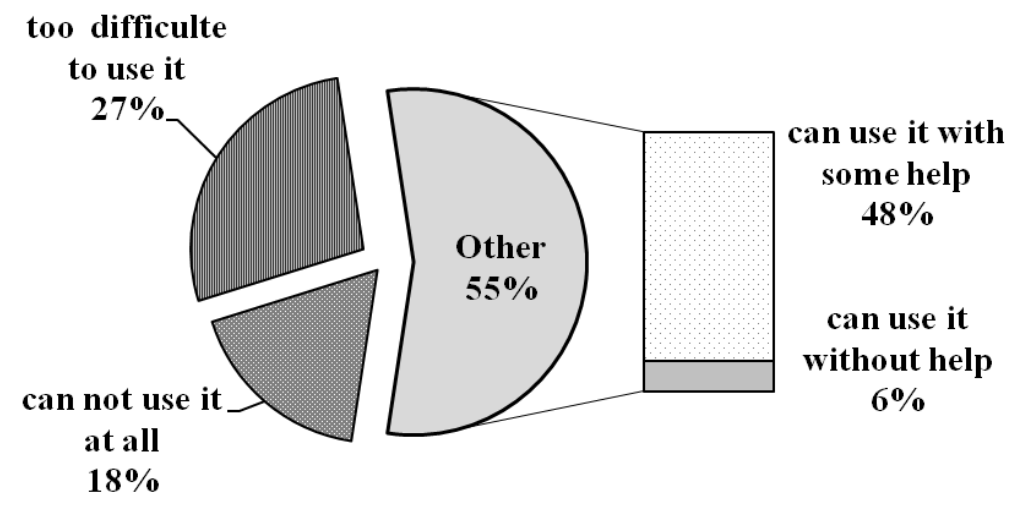

Figure 2: Self-evaluated students' capabilities of English language textbooks and literature usage in General Chemistry course

Only $6 \%$ of the students can use in English literature without help, but $18 \%$ of students do not have language skills to use it at all. From 69 students, $76 \%$ of students can utilize study materials in English, but with a help or with some difficulties. It is interesting to note that $56 \%$ of students reported knowledge of German as a second language followed by French 
and 1-2\% students having a basic knowledge of Italian, Spanish, Russian and Arabic language.

\section{$3.4 Q C$ results and discussion}

In the next two questions, we collected answers related to the number of study hours per week for corresponding courses.

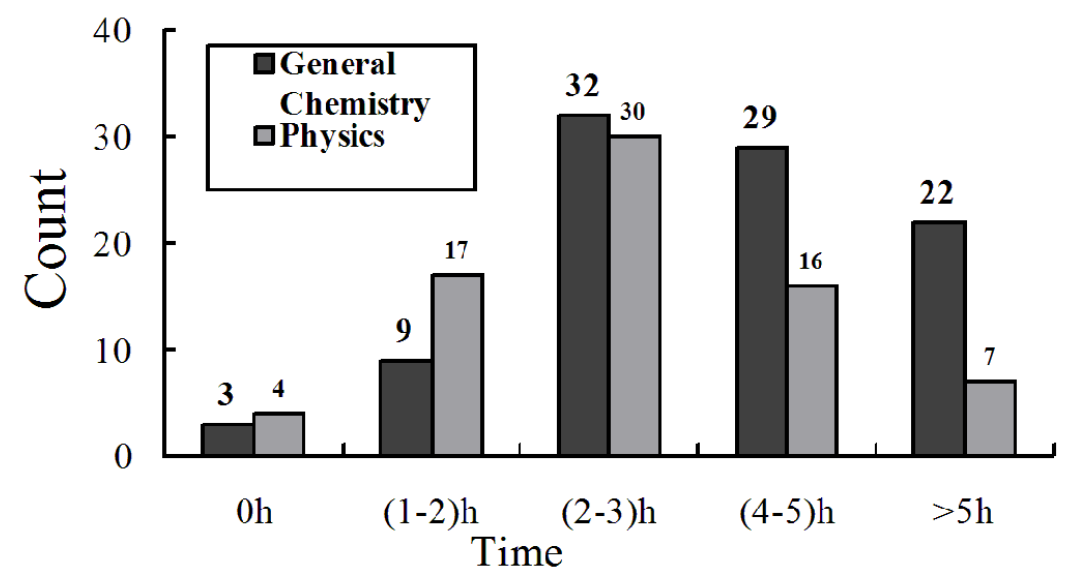

Figure 3: Distribution of students (\%) by time spent on studying for General Chemistry and General Physics exam per week

Results presented on Figure 3 show that there are 3-4\% of students who do not study at all, or spend 1-2 h studying (average $13.5 \%$ of students) that clearly is not enough time even to prepare lab reports and other weekly assignments. Majority of students (31\%) spend 2-3 hours per week covering new study material while syllabus for mentioned courses calls for 6 hours of independent work. These criteria are met by approximately $15 \%$ of students. Without achieved competencies in study areas of programs where in addition to expected knowledge in their field of study, understanding and using study materials in foreign language is expected, students will have tremendous obstacles following globalization trends in education. There are a number of expected competencies and skills that students need to achieve assuring them an easy transition to any other educational system particularly the ones following the Bologna system. A profile of ideal mobility student shows a set of skills and behavioral characteristics such as different interpersonal skills, habits, linguistics, educational credentials, academic records, knowledge of the second language, and lifestyle preferences (Zepke \& Leach, 2010). Lack of those skills limits the students' participation in any of offered international programs and hampers the implementation of Bologna system in this particular geographic area.

\section{$3.4 Q D$ results and discussion}

QD group of questions was related to information on students' attitudes toward their potential participation in mobility programs during and after their undergraduate studies. Most students did not choose any of offered options (45\%), while $23 \%$ of students would like to continue their graduate studies preferably at the university outside of $\mathrm{BiH}$ (the most popular 


\section{Macrothink}

universities are in EU). Participation in an international project was chosen by $7 \%$ of students, and only $6 \%$ of students would take part in some of the programs of international exchange (Figure 4).

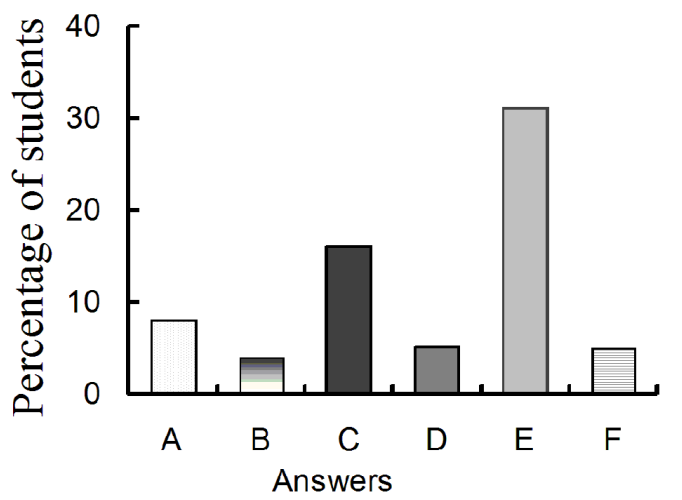

Figure 4: Students interest in continued education on foreign universities or participation in international education programs.

Description for above figure: A-continue studies in EU countries; B-participate in student exchange program; C-enrolled in foreign postgraduate program; D-participate in international educational projects; E-none of offered answers; F-no answer

When results displayed in Figure 4 are summarized we found that there are around $35 \%$ of students in this pilot research study who did not accept any of offered answers which emphasizes the negative trend in terms of international education influences. One can suppose, based on these answers, they are not interested in acquiring any experience abroad. Regarding the mobility programs participants have to be firstly more informed and secondly more motivated to consider such opportunities that they have at the equal level as many of their colleagues in the many higher education institutions around Europe or wider. Somewhat different responses to the question assessing the importance of the knowledge acquired at universities outside of $\mathrm{BiH}$ (Figure 5) were received.

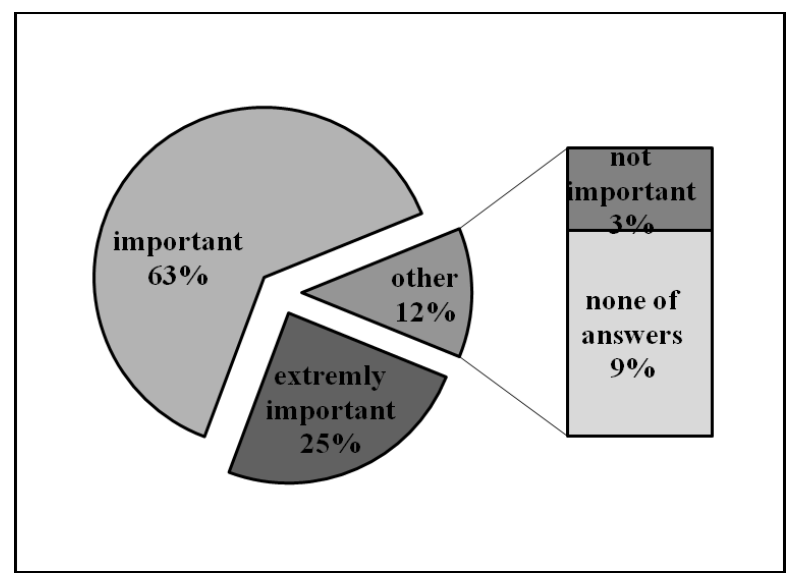

Figure 5: Percentage chart of students' answers on importance of education acquired on foreign universities 
Most students answered that a knowledge and skills acquired studying on universities outside of $\mathrm{BiH}$ are important (87\%), while others believe that it is not important (4\%), and $9 \%$ of students do not agree with any of offered answers. On the question, dealing with evaluation of quality of educational systems in the world, students had nine options for answers: EU countries, USA, Canada, Great Britain, Australia, Malaysia, Asia, and Eastern Europe and Arab Countries). Great Britain and Malaysia are here added separately because of general opinion among the students that their educational systems is somewhat different from countries in a particular region (even objectively that does not have to be case). The best are according to students' opinion universities in Europe (36\%) mainly Austria and Germany, followed by USA (28\%) while $20 \%$ of students said they have no information on education systems in any of these countries. These answers actually confirm our hypothesis about limited involvement of our students in global educational trends. Students based their answers on limited information usually received from friends and family members either living permanently or studying in these countries. Interestingly some of the EU countries well known by high quality education systems are not even mentioned in answers. This clearly shows that students base their opinion on geographical closeness, limited language knowledge or private information they received. Nevertheless, in general, test results are in agreement with UN report (Altbach et al., 2009) on student mobility showing two main trends. One consists of students from Asia entering the major academic systems of North America, Western Europe, and Australia. The other trend within the European Union largely reflects a South-North mobility phenomenon.

\section{Summary}

Is the method of integrated science and second languages knowledge an adequate content for increasing the abilities and willingness of $\mathrm{BiH}$ chemistry students to be involved in a mobility program? Questionnaire analysis showed that first year students, who have been subject to research, showed that they do not have the necessary competencies not only in English or another foreign language knowledge for professional use, but also for possible participation in the programs of student mobility that is one of main goals set out in documents on Bologna process. Furthermore, the results showed that students have difficulties to achieve competency in science knowledge, do not invest enough time studying for exams in general chemistry and physics, and do not understand the necessity of participation in the process of internationalization in the field higher education. In the same context are our findings to the RQ2. We consider that the method of integrated science and second language knowledge is an adequate content for increasing abilities of students to be involved in a mobility program that has to be based on higher students' motivation and commitment to accept the global approach in the area of international education. Therefore, a main role for every higher education institution is to establish the strategies of a change in approach for creation and improvement of a framework at higher international education level. It means that a mobility student between two universities might define a large network, "and the links are student mobility between them" (Derzsi, et al., 2011).

Students from $\mathrm{BiH}$ have the same opportunities as other students in Europe and the world, what is confirmed by the message from ministers meeting in Budapest and Vienna (2010) 
explaining "to enable students and staff to be mobile, to improve teaching and learning in higher education institutions, to enhance graduate employability, and to provide quality higher education for all". Development of awareness of global education model is necessary first step towards improvement of student's competencies and skills that will result in higher participation in current global trends in education.

\section{References}

Altbach, P.G., Reisberg, L., \& Rumbley, L.E. (2009). Trends in Global Higher Education: Tracking an Academic Revolution, Executive Summary. A Report Prepared for the UNESCO 2009 World Conference on Higher Education. Retrieved from: http://unesdoc.unesco.org/images/0018/001832/183219e.pdf (September 2, 2011)

Benelux (2009). Communiqué of the Conference of European Ministers Responsible for Higher Education: The Bologna Process 2020 - The European Higher Education Area in the new decade, Leuven and Louvain-la-Neuve, 28-29 April 2009. Retrieved from: http://europa.eu/legislation_summaries/education_training_youth/lifelong_learning/c11088_e n.htm (September 2, 2011)

Bergen (2005). Communiqué of the Conference of European Ministers Responsible for Higher Education: The European Higher Education Area - Achieving the Goals, Bergen, 19-20 May. Retrieved from: http://europa.eu/legislation_summaries/education_training_youth/lifelong_learning/c11088_e n.htm (September 2, 2011)

Brodin, J. (2010). Education for Global Competencies An EU-Canada Exchange Programme in Higher Education and Training. Journal of Studies in International Education, 14(5), 569-584. http://dx.doi.org/10.1177/1028315309343616

Brux, J.M., \& Fry, B. (2010). Multicultural Students in Study Abroad: Their Interests, Their Issues, and Their Constraints, Journal of Studies in International Education, 14 (5), 508-527. http://dx.doi.org/10.1177/1028315309342486

Budapest and Vienna (2010). Budapest-Vienna Declaration on the European Higher Education. Retrieved from: http://europa.eu/legislation_summaries/education_training_youth/lifelong_learning/c11088_e n.htm (September 2, 2011)

Davila, K., \& Talanquer, V. (2010). Classifying End-of-Chapter Questions and Problems for Selected General Chemistry Textbooks Used in the United States, Journal of Chemical Education, 87(1), 97-101. http://dx.doi.org/10.1021/ed8000232

Derzsi, A., Derzsy, N., Kaptalan, E., \& Neda, Z. (2011). Topology of the Erasmus student mobility network, Physica A, $390 \quad$ (13), 2601-2610. http://dx.doi.org/10.1016/j.physa.2011.02.041

Erichsen, E.A., \& Goldenstein, C. (2011). Fostering Collaborative and Interdisciplinary 


\section{Macrothink}

International Journal of Education

ISSN 1948-5476

2012, Vol. 4, No. 1

Research in Adult Education: Interactive Resource Guides, and Tools, SAGE Open, I-II. http://dx.doi.org/10.1177/2158244011403804

Heyneman, S., Farrell, J., \& Sepuvelda-Situardo, M. (1978). Textbooks and Achievements: What We Know. Washington DC: The World Bank.

Salisbury, M.H., Umbach, P.D., Paulsen, M.B., \& Pascarella, E.T. (2009). Going global: Understanding the choice process of the intent to study abroad. Research in Higher Education, 50(2), 119-143. http://dx.doi.org/10.1007/s11162-008-9111-x

Tarrant, M.A. ( 2009). A Conceptual Framework for Exploring the Role of Studies Abroad in Nurturing Global Citizenship. Journal of Studies in International Education, 14 (5). 433-457. http://dx.doi.org/10.1177/1028315309348737

Washington, D.D. (1998). African-American undergraduate students' perceptions of and attitudes toward study abroad programs. Doctoral dissertation, George Mason University, Fairfax, Virginia. (UMI No. 9901923)

Zepke, N., \& Leach, L. (2010). Beyond hard outcomes: 'soft' outcomes and engagement as students success, Teaching in Higher Education, 15(6), 661-673. http://dx.doi.org/10.1080/13562517.2010.522084

\section{Glossary}

BiH: Bosnia and Herzegovina.

EU: European Union

QA: selected questions in the group A.

QB: selected questions in the group B.

QC: selected questions in the group C.

QD: selected questions in the group D.

PP: PowerPoint presentation

RQ1: the research question number 1

RQ2: the research question number 2

\section{Appendix}

Appendix 1. Questionnaire as a tool for a diagnostic pilot research study 


\section{QUESTIONAIRE}

To answer the following questions, please circle the answer according to the following scale
1 (not at all)
2 (rarely)
3 (sometimes)
4 (often)
5 (very often)

\section{$\underline{\text { QA }(1,2,3)}$}

1. For learning and exam preparation in General Chemistry, I use the following sources:
a) textbook recommended in syllabus:

1
1
1
1
1
1
1
1
1

$\begin{array}{llll}2 & 3 & 4 & 5\end{array}$
b) problems and exercises study book:

$\begin{array}{llll}2 & 3 & 4 & 5\end{array}$
c) lab manual:
d) recommeded textbook in English language:

23

45
e) internet sources:

2

$4 \quad 5$
f) not recommended literature:
g) Power Point presentations:
h) lecture notes:
i) senior students' notes:

$\begin{array}{llll}2 & 3 & 4 & 5 \\ 2 & 3 & 4 & 5 \\ 2 & 3 & 4 & 5 \\ 2 & 3 & 4 & 5 \\ 2 & 3 & 4 & 5\end{array}$

2. For learning and exam preparation in General Physics, I use the following sources:

$\begin{array}{llllll}\text { a) textbook recommended in syllabus: } & 1 & 2 & 3 & 4 & 5 \\ \text { b) problems and exercises study book: } & 1 & 2 & 3 & 4 & 5 \\ \text { c) lab manual: } & 1 & 2 & 3 & 4 & 5 \\ \text { d) recommended textbook in English language: } & 1 & 2 & 3 & 4 & 5 \\ \text { e) internet sources: } & 1 & 2 & 3 & 4 & 5 \\ \text { f) not recommended literature: } & 1 & 2 & 3 & 4 & 5 \\ \text { g) Power Point presentations: } & 1 & 2 & 3 & 4 & 5 \\ \text { h) lecture notes: } & 1 & 2 & 3 & 4 & 5 \\ \text { i) senior students' notes: } & 1 & 2 & 3 & 4 & 5\end{array}$

3. If you are using recommended textbook please answer following:

General Chemistry I: a) Title:

b)

Authors:

General Physics I: a) Title:

b)

Authors:

\section{Please circle the best answer}

\section{$\mathrm{QB}(4,5,6)$}

4) My English language proficiency is:
a) do not know English
b) poor
c) good
d) very good
e) excellent is: 

a) do not know other language
b) poor
c) good
d) very good
e) excellent

6) I can use English language literature for General Chemistry and Physics exam preparation:
a) not at all
b) hardly
c) with a little help
e) without any difficulties

\section{$\underline{\mathrm{QC}(7,8)}$}

7) How many hours do you spend on studying for General Chemistry exam per week?
a) 0 b) 1 hour c) 2-3 hours
d) 4-5 hours
e) more than 5 hours
f) other (please specify)

8) How many hours do you spend on studying for General Physics exam per week:
a) 0 b) 1 hour c) 2-3 hours
d) 4-5 hours
e) more than 5 hours
f) other (please specify)

\section{$\underline{\text { QD }(9,10,11)}$}

9) I am planning to continue my education/career development.....
a) in some other country in Europe
b) by participating in a student exchange program
c) by enrolling in a graduate program outside of $\mathrm{BiH}$
d) by participating in international educational projects
e) none of the answers

10) The best higher education system according to my opinion is in:
a) European Union, (Country)
b) USA
c) Canada
d) Australia
e) Great Britain
f) East-European Countries
g) Arab countries
h) Malaysia
i) I do not have information about educational system in these countries

11) Importance of education acquired on institutions of higher education outside of $\mathrm{BiH}$ is:
a)extremly important
b)important
c)not important
d)none of the answers
e)other (please specify)

\section{Copyright Disclaimer}

Copyright reserved by the author(s).

This article is an open-access article distributed under the terms and conditions of the Creative Commons Attribution license (http://creativecommons.org/licenses/by/3.0/). 